\title{
A Northern River Terrapin (Batagur baska) from Kutch, with Comments on the Species' Distribution in Western India and Pakistan
}

\author{
Raju Vyas
}

Fatehgunj, Vadodara, Gujarat, India (razoovyas@hotmail.com)

$\mathrm{T}$

The Northern River Terrapin (Batagur baska) is a large turtle first described by British zoologist John Edward Gray (1930) based on an illustration in Gray (1833-1834) labeled "BATAGUR TERRAPIN n EMYS BATAGUR n." (Fig. 1). It is the only riverine hard-shelled turtle that has four claws on each foot. These turtles inhabit estuaries, mangrove swamps, brackish waters, and inshore beds of marine vegetation. This species is endangered throughout its range and has been extirpated in many areas. It is legally protected as a "Schedule I" species under the Indian Wildlife Protection Act of 1972, and is listed as Critically Endangered on the IUCN Red List of Threatened Species (Asian Turtle Working Group 2000).

The historical literature indicates that $B$. baska was largely confined to mangrove habitats in river deltas and large estuaries in eastern India (Orissa and West Bengal), Bangladesh, Myanmar, Thailand, Cambodia, Vietnam, western Malaysia, and Indonesia (Smith 1931; Moll 1980; Das 1985, 1991, 1995; Ernst et al. 2000; Platt et al. 2003; Fritz and Havaš 2007), although Praschag et al. (2008) indicated that the populations from Malaysia and Indonesia represent a distinct species. However, none of those surveys considered the species' distribution along the River Indus. Murray (1884; Fig. 2) had reported the presence of the species in the River Indus, and Marshall (1931; Fig. 3) had supported the distribution of the species in the Indus on the basis of shell fragments found in the ruins of Mohan-jo-daro (one of the oldest centers of Indus Valley civilization, dating back to 3,300 BC). Tikader and Sharma (1985) and Sharma (1998) mentioned that "fragments" of this species have also been recorded from the "Mohan-jo-Daro" and "Harappa" sites, and Das (2010) supported the historical record of the species from southern Pakistan. However, most subsequent surveys of Pakistani rep-
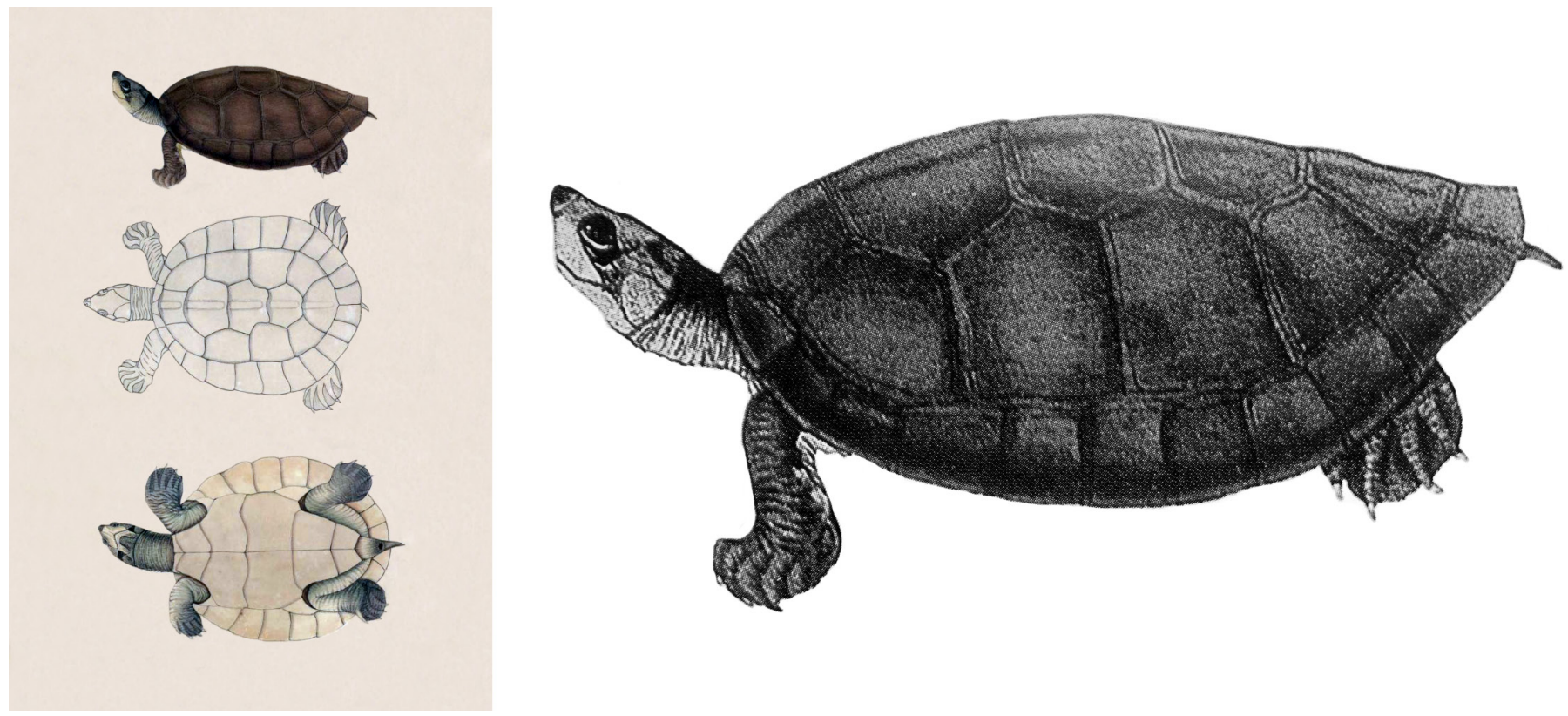

Fig. 1. The Northern River Terrapin (Batagur baska) was described by British zoologist John Edward Gray (1830) based on an illustration labeled “BATAGUR TERRAPIN n EMYS BATAGUR n. from Dr. Buchanan Hamilton's drawing” that appeared in Gray (1833-1834). 
Batagur baska, Gray, Sh. Rept., p. 35, tab. 16 ; Gunth. Rept. Br

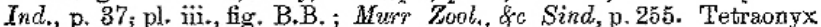
baska, Buch. Ham. MSS. Groy, Ill. Ind. Zool.; Theob. Rept. Br.

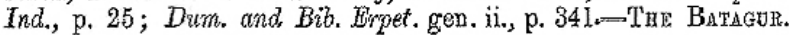

Toes four on all feet. Axterior half of shell elevated and convex, posterior much depressed and flattened; the greatest width behind its sternum truncated in front. Carapace smooth and polished.

Nuchal plate sub-quadrangulsr, four anterior vertebrals sub-quadrangular, nearly as broad as long; the fiftl hexagonal. Caudal plates square, separated by a suture, without notch behind. Head covered with undivided skin; snout rather pointed; nose turmed upwards. Upper jaw denticulated. Colour uniform brown. Grows from 20 to 24 inches.

Hab.-The river Indus; Ganges, Irawaddy, Hooghly, Pegu and Tenasserim. Considered wholesome food.

Fig. 2. The description of the Northern River Terrapin (Batagur baska) from the Indus River in Murray (1884, p. 341).

Batagur baska?
SD 188 , depth $4 \mathrm{ft.} 2$ in. Part of a plastron that has been sawn square.
VS 720 , depth $9-13$ ft. Part of a plastron.
It is with some hesitation that I record this species. The plastron (SD 188 ) has clearly
been sawn, so that the remaining plate is square. I have compared this plate with the
corresponding part of the skeleton of a specimen in the collection of the Zoological Survey of
India, and the similarity is so close that I believe them to belong to the same species. On the
other hand, however, the distribution of Batagur baska, as given by Boulenger (Fauna of British
India, Reptilia, p. 38 ) is "Bengal, Burma, Malay Peninsula ". It is possible, therefore, that
the specimen may belong to some other species ; but equally it is possible that at the time
when Mohenjo-daro was an inhabited city this river turtle was living in the Indus. That
the remains were contemporaneous with the Mohenjo-daro civilization is clear from the fact
that the bone has been sawn into a square to serve some definite purpose.

Fig. 3. Reference to the Northern River Terrapin (Batagur baska) in Marshall (1931, pp. 663-664).

tiles (Minton 1966; Azam et al. 2005; Khan 2006; Wahab et al. 2012) omitted any mention of this species. More recently, Praschag et al. (2008) and Moll et al. (2009), in accounts of the species, did allude to historical records of the species from the Indus (Pakistan) and the Brahminy-Baitarini Delta (Orissa) with a caution that those data required confirmation. Further, Praschag et al. (2008) used mtDNA sequences to link a museum specimen, a stuffed sub-adult male $B$. baska from the Indus Delta in Sindh Province, Pakistan (Naturhistorisches Museum Wien, NHMW 1841; Grillitsch et al. 1996), to the "northern species." Also, although not rul- ing out the possibility of a misstated locality, they noted that: "... taking into account the large-scale extirpation of these large estuarine terrapins and the rarity of historical records, a former occurrence in the Indus Delta seems possible, especially when it is considered that several other freshwater turtle species are distributed in the Indus as well as in the Ganges systems (Iverson 1992; Ernst et al. 2000)."

\section{A New Record}

Recently, a record of a large adult turtle surfaced on social media. On 17 April 2016, I noticed on Facebook a request by a local wildlife expert for identification/confirmation of the turtle species. It was accompanied by photographs (Fig. 4) that depicted a large turtle (approx. $60 \mathrm{~cm}$ ) that a local fisherman found trapped in his net. This dark gray turtle with an olive-gray head and webbed feet (with four claws on each foot) was caught at the Rudramata Dam $\left(23^{\circ} 21^{\prime} 41.24^{\prime \prime} \mathrm{N}\right.$, $69^{\circ} 42^{\prime} 21.41$ ”E), at more than $8.2 \mathrm{~km}^{2}$, the largest body of water body in Kutch (= Kachchh) District, Gujarat State (the westernmost state in India). The curious fisherman, who had never seen a turtle this large and was totally unaware of its significance and legal status, kept the turtle for several days, during which he initiated inquiries among local wildlife enthusiasts. An unusual turtle of these proportions found in Kutch was noteworthy, and the discovery was soon relayed on electronic media, which generated information about its protected status under the Indian Wildlife Protection Act of 1972. Concerned, the fisherman immediately released the turtle into nearby Pragsar Lake $\left(23^{\circ} 9^{\prime} 6.76^{\prime \prime} \mathrm{N}, 69^{\circ} 28^{\prime} 45.09^{\prime \prime} \mathrm{E}\right)$ before anyone could intervene and confirm or properly identify it as a female Northern River Terrapin (Batagur baska).

A large female turtle accidently caught from an inland body of water in Kutch raises certain questions. Rudramata Dam is situated on the northern edge of Great Rann (a seasonal salt marsh). Two possibilities are reasonable: (1) It could
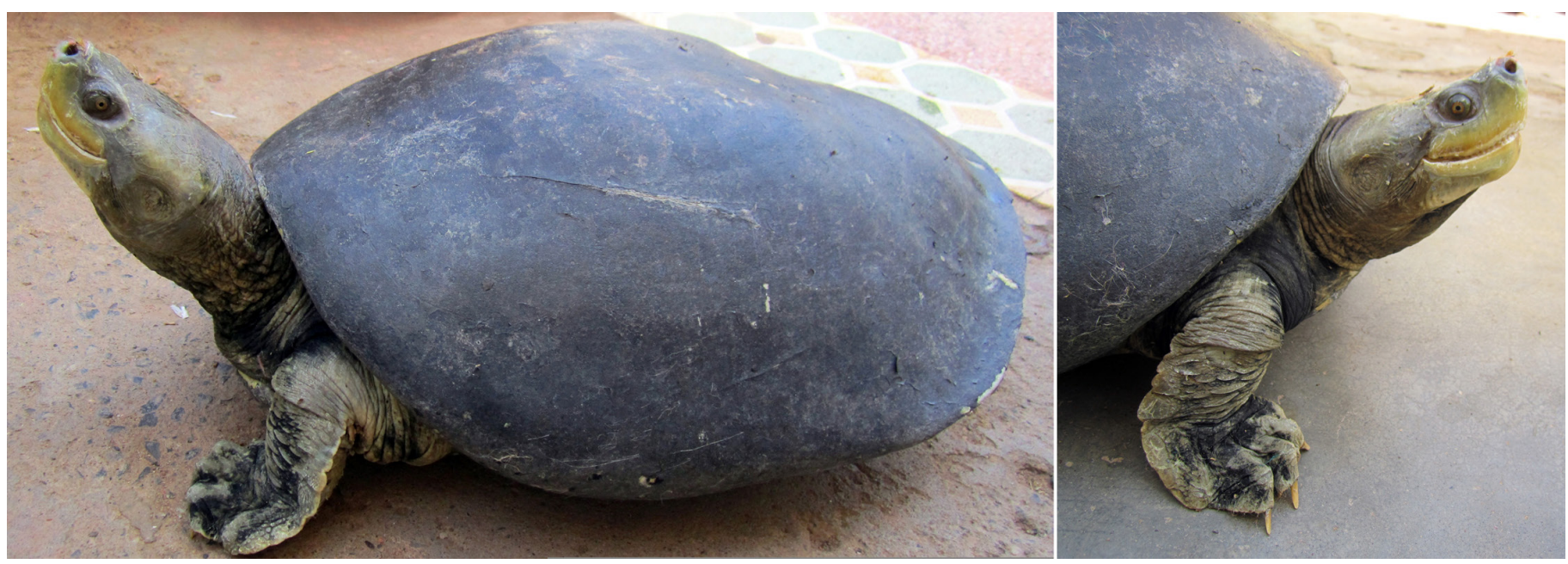

Fig. 4. A Northern River Terrapin (Batagur baska) caught accidently by a local fisherman from Rudramata Dam, Bhuj, Kutch, Gujarat. Photograph by Kartik A. Pomal. 
have been an illegal pet released by its owner, or (2) it might be a natural inhabitant of the area.

Reptiles, especially turtles and tortoises, are increasingly popular in the pet trade (e.g., Vyas 2012, 2015; D'Cruze et al. 2015; Mendiratta et al. 2017). Conversations with locals, who are involved in such activities, elicited responses to questions like: "Is the pet trade prevalent in the region?" and, "If yes, what species are most likely involved?" that revealed no direct evidence of any pet trade in live animals, especially involving reptilian species beyond an ongoing demand for a small number of native species like the Indian Star Tortoise (Geochelone elegans) or invasive species, such as the Red-eared Slider (Trachemys scripta elegans). Some illegal trapping of freshwater turtles, including Indian Flap-shelled Turtles (Lissemys punctata) and Ganges Soft-shelled Turtles (Nilssonia gangetica), occurs for consumption (including eggs) and export (adults) to other parts of the country, but such activities should increase the likelihood of discovering a large terrapin, which obviously is not happening.

The natural presence of the species is hypothetically possible. In 1819, an earthquake in Kutch created a huge natural dam, the Allah Bund, almost $120 \mathrm{~km}$ long and up to $25 \mathrm{~km}$ wide, that disrupted the flow of the Eastern Nara Branch of the Indus, which used to flow through the northeastern corner of a seasonal saltmarsh called the Great Rann (Thakkar et al. 2012). The Rudramata Reservoir, on the southern edge of the Great Rann, receives water from the Pur River, which then flows toward the Banni grasslands and into the Great Rann via Sumarasar and Nenu Nidhar (ancient civilization sites). Since Murray (1884) and Marshall (1931) indicated that these waters historically supported a population of Northern River Terrapins, the possibility that the species inhabits the current day Indus and its tributaries is not unreasonable. Furthermore, the Indus estuaries and adjoining wetlands harbor suitable habitat in the form of ample mangrove swamps, which extend all the way to the Marine National Park \& Sanctuary in the Gulf of Kutch.

In principle, either possibility might account for the occurrence of this critically endangered turtle species in the Kutch. The captured female could have arrived via the pet trade or she might be part of a remnant natural population. Thorough surveys of the extensive inland bodies of water in the Kutch are physically impossible, especially if extended as far as the coastal mangrove habitats that extend beyond the border with Pakistan, particularly in the politically disputed areas known as Sir and Kori Creeks. The mangrove forests surrounding the latter, although less diverse today than at the height of the Indus civilization, remain among the most pristine of any in either India or Pakistan (Shah et al. 2007; Singh 2007; Kalhoro et al. 2016) — and all have the potential to support relict populations of this species.
Ultimately, the possible presence of such populations can be confirmed only by extensive research and surveys in the region. These could be supplemented by employing environmental DNA (eDNA) detection methods (e.g., Davy et al. 2015), although users of such methods must consider potentially confounding environmental factors and the likelihood of false negatives when searching for species present only in very small numbers. Also, any DNA collected, whether environmental or extracted from a captured animal should be compared to the only known source of DNA from the Indus (MHNW 1841; Praschag et al. 2008), as genetic differences between natural populations of turtles from the Indus and Ganges systems would be expected. Nevertheless, these methods have great potential for detecting the presence of rare species.

\section{Acknowledgements}

I thank Mr. J.K. Tiwari (Moti Virani, Kutch) and Dr. Divyesh Gadhavi (Dy. Director, The Corbett Foundation, Naliya, Kutch) for sharing valuable information and helping me trace pet-trade activities. I also thank Mr. Kartik A. Pomal (Bhuj, Kutch) for the use of his photograph. The Deputy Conservator of Forest, Forest Department, Gujarat provided support and ongoing help.

\section{Literature Cited}

Asian Turtle Working Group. 2000. Batagur baska. The IUCN Red List of Threatened Species 2000: e.T2614A97331162 (http://www.iucnredlist.org/ details/full/2614/0)

Azam, M.M., M.S. Fakhri, and Saifullah. 2005. Some observations on the distribution and abundance of freshwater turtles in the River Indus. Record of Zoological Survey Pakistan 16: 46-51.

Das, I. 1985. Indian Turtles - A Field Guide. World Wildlife Fund-India (Eastern region), Calcutta, India.

Das, I. 1991. Colour Guide to The Turtles and Tortoises of the Indian Subcontinent. R \& A Publishing Ltd., Portishead, UK.

Das, I. 1995. Turtles and Tortoises of India. World Wide Fund for Nature - India, Oxford University Press, Bombay, India.

Das, I. 2010. A Field Guide to the Reptiles of South-east Asia. New Holland Publishers Ltd., London, UK.

Davy, C.M., A.G. Kidd, and C.C. Wilson. 2015. Development and validation of environmental DNA (eDNA) markers for detection of freshwater turtles. PLoS ONE 10(7): e0130965 (https://doi.org/10.1371/journal. pone.0130965).

D'Cruze, N., B. Singh, T. Morrison, J. Schmidt-Burbach, D.W. Macdonald, and A. Mookerjee. 2015. A star attraction: The illegal trade in Indian Star Tortoises. Nature Conservation 13: 1-19.

Ernst, C.H., R.G.M. Altenburg, and R.W. Barbour. 2000. Turtles of the World - CD-ROM edition. ETI Expert Center for Taxonomic Identification, Amsterdam, UNESCO Publishing, Paris, and Springer Verlag, Heidelberg and New York.

Fritz, U. and P. Havaš (comp.). 2007. Checklist of chelonians of the world. Vertebrate Zoology 57: 149-368.

Gray, J.E. 1830. A synopsis of the species of the Class Reptilia, pp. 2-21. In: E. Griffith and E. Pidgeon, The Class Reptilia Arranged by the Baron Cuvier, with specific descriptions. In: E. Griffith (ed.), The Animal Kingdom Arranged in Conformity with its Organization, by the Baron Cuvier, with Additional Descriptions of All the Species Hitherto Named, and of Many Before Noticed. Vol. 9. Reptila. Supplement. Whittaker, Treacher and Co., London, UK. 
Gray, J.E. 1833-1834. Illustrations of Indian Zoology; Chiefly Selected from the Collection of Major-General Hardwicke, F.R.S. Vol. II. Adolphus Richter and Co., London, UK.

Grillitsch, H., E. Schleiffer, and F. Tiedemann. 1996. Katalog der Trockenpräparate der Herpetologischen Sammlung des Naturhistorischen Museums in Wien. Stand: 31. Dezember 1995. Kataloge der wissenschaftlichen Sammlungen 11, Vertebrata 5: xiv + 140 pp. +11 Tables.

Iverson, J.B. 1992. A Revised Checklist with Distribution Maps of the Turtles of the World. Privately Printed, Richmond, Indiana.

Kalhoro, N.A., Z. He, D. Xu, M. Faiz, L.V. Yafei, N. Sohoo, and A.H. Bhutto. 2016. Vulnerability of the Indus River Delta of the North Arabian Sea, Pakistan. Global NEST Journal 18: 599-610.

Khan, M.S. 2006. Amphibians and Reptiles of Pakistan. Krieger Publishing Co., Malabar, Florida, USA.

Marshall, J. (ed.). 1931. Mohenjo-Daro and Indus Civilization, Volume II. Arthur Probsthain, London, UK.

Mendiratta, U., V. Sheel, and S. Singh. 2017. Enforcement seizures reveal large-scale illegal trade in India's tortoises and freshwater turtles. Biological Conservation 207: 100-105.

Minton, S.A. 1966. A contribution to the herpetology of West Pakistan. Bulletin of the American Museum of Natural History 134: 27-184.

Moll, E.O. 1980. Natural History of the river terrapin, Batagur baska (Gray) in Malaysia (Testudines: Emydidae). Malaysian Journal of Science 6(A): 23-62.

Moll, E.O., K. Platt, S.G. Platt, P. Praschag and P.P. van Dijk. 2009. Batagur baska (Gray 1830) - Northern River Terrapin. In: A.G.J. Rhodin, P.C.H. Pritchard, P.P. van Dijk, R.A. Saumure, K.A. Buhlmann, J.B. Iverson, and R.A. Mittermeier (eds.), Conservation Biology of Freshwater Turtles and Tortoises: A Compilation Project of the IUCN/SSC Tortoise and Freshwater Turtle Specialist Group. Chelonian Research Monographs 5: 037.1-037.10 (http://www.iucn-tftsg.org/cbftt/).
Murray, J.A. 1884. The Vertebrate Zoology of Sind. Richardson \& Co., London, UK.

Platt, S.G., B.L. Stuart, H. Sovannara, L. Kheng, Kalyar, and H. Kimchhay. 2003. Rediscovery of the critically endangered river terrapin, Batagur baska, in Cambodia, with notes on occurrence, reproduction, and conservation status. Chelonian Conservation and Biology 4: 691-695.

Praschag, P., R.S. Sommer, C. McCarthy, R. Gemel, and U. Fritz. 2008. Naming one of the world's rarest chelonians, the southern Batagur. Zootaxa 1758: 61-68.

Shah, A.A., I. Kasawani and J. Kamaruzaman. 2007. Degradation of Indus Delta mangroves in Pakistan. International Journal of Geology 3: 27-34.

Smith, M.A. 1931. The Fauna of British India, including Ceylon and Burma. Reptilia and Amphibia, Vol. 1 - Loricata, Testudines. Taylor and Francis, London, UK.

Singh, H.S. 2007. Mangroves in Gujarat (Current Status and Strategy for Conservation). Gujarat Ecological Education \& Research (GEER) Foundation, Gandhingar, India.

Sharma, R.C. 1998. Fauna of India, Reptilia - Testudines and Crocodilians, Volume: I. Zoological Survey of India, Calcutta, India.

Thakkar, M.G, M. Ngangom, P.S. Thakker and N. Juyal. 2012. Terrain response to the 1819 Allah Bund earthquake in western Great Rann of Kachchh, Gujarat, India. Current Science 103: 208-212.

Tikader, B.K. and R.C. Sharma. 1985. Handbook: Indian Testudines. Zoological Survey of India, Calcutta, India.

Vyas, R. 2012. Notes on the trade in, and its effects on, the Red Sand Boa (Eryx johnii johnii) in Gujarat, India. Sauria 34(2): 3-8.

Vyas, R. 2015. Jeopardized future of Indian Star Tortoise Geochelone elegans. Reptile Rap 17: 13-18.

Wahab, A., K. Saeed, M.M. Azam, and S.M. Nasir. 2012. Distribution and Status of Threatened Species of Freshwater Turtles in Selected Areas of Indus River System. Zoological Survey of Pakistan, Ministry of Climate Change, Islamabad, Pakistan. 